\title{
The Relationship Between Neutrophil-Lymphocyte Ratio and Empirical Antibiotic Therapy in Patients with Fever of Unknown Origin
}

\author{
Nedeni Bilinmeyen Ateşli Hastalarda Nötrofil-Lenfosit Oranı ile Ampirik \\ Antibiyotik Tedavisi Arasındaki İlişki
}

\author{
Cengiz Karacaer ${ }^{1}$, Oğuz Karabay², Ali Tamer ${ }^{1}$ \\ ${ }^{1}$ Sakarya Üniversitesi Eğitim ve Araştırma Hastanesi, İ̧̧ Hastalıkları Anabilim Dalı, Sakarya \\ Yazı̧̧a Adresi / Correspondence: \\ Cengiz Karacaer \\ Sakarya Eğitim ve Araştırma Hastanesi, İç Hastalıkları Anabilim Dalı, Sakarya \\ T: +90505740 0168 E-mail : karacaerc@yahoo.com \\ Geliş Tarihi / Received : 20.10.2020 Kabul Tarihi / Accepted : 06.12.2020 \\ Orcid : \\ Cengiz Karacaer , https://orcid.org/0000-0002-7164-4810 \\ Oğuz Karabay https://orcid.org/0000-0003-1514-1685 \\ Ali Tamer https://orcid.org/0000-0003-2005-0737 \\ ( Sakarya Tip Dergisi / Sakarya Med J 2021, 11(1):25-31 ) DoI: 10.31832/smj.813151
}

${ }^{2}$ Sakarya Üniversitesi Eğitim ve Araştırma Hastanesi, Enfeksiyon Hastalıkları ve Klinik Mikrobiyoloji Hast. Anabilim Dalı, Sakarya

\footnotetext{
Abstract

Objective Empirical antibiotic therapy is usually applied by physicians to patients with fever when the origin of the infection can not yet be determined. The aim of this study is to determine the cost-effectiveinflammatoryparametersin empirical antibiotic therapy in patients with fever of unknown origin(FUO).

Materials A total of 577 patients, whose blood cultures were taken and followed up by the NBA, were divided into two groups as fever group due to infection(IRFG) and fever group and Methods not related to infection(NIRFG), and their five-year data were analyzed retrospectively from the patient information registry system. From the complete blood count test results, the neutrophil count was proportioned to the lymphocyte count parameter, and the neutrophil lymphocyte ratio and thrombocyte lymphocyte ratio values were calculated.

Results Total of 577 patients were divided into two groups as infection related fever group (IRFG) and non-infection related fever group (NIRFG), and were included in the study. The durations of first antibiotic usages were $4.54 \pm 3.08(1-14)$ days and $5.35 \pm 3.8(1-21)$ days in IRFG and NIRFG, respectively. Neutrophil-to-lymphocyte ratio (NLR) was $8.00(3.00-15.00)$ in the IRFG, whereas it was $5.00(3.00-9)$ in the NIRFG $(\mathrm{p}=0.001)$. Platelet-to-lymphocyte ratio (PLR) was $21.00(9.00-41.00)$ in the IRFG, whereas it was $16.00(7.25-27.75)$ in the NIRFG and was not significant $(\mathrm{p}=0.165)$.

Conclusion Since neutrophil-lymphocyte ratio can be checked from routine blood tests and is not an expensive method, it can be used as an advantageous diagnostic method in patients with fever of unknown origin(FUO).

Keywords Empirical antibiotic therapy; Fever of unknown origin; Neutrophil to lymphocyte ratio; Platelet-to-lymphocyte ratio.

$\ddot{\mathrm{O} z}$

Amaç Ampirik antibiyotik tedavisi, enfeksiyon kaynağının henüz belirlenemediği durumlarda hekimlerin ateşi olan hastalara yaygın olarak uyguladıkları bir yöntemdir. Bu çalı̧̧manın amacı, nedeni bilinmeyen ateși olan hastalarda (NBA) ampirik antibiyotik tedavisinde maliyet-etkinin flamatuar parametreleri belirlemektir.

Gereç ve Kan kültürleri alnmış olan NBA ile takip edilen toplam 577 hasta enfeksiyona bağhl ateş grubu (EBAG,n:203) ve enfeksiyona bağlı olmayan ateş grubu (EBOAG, n:374) olarak iki gruba ayrıld Yöntemler ve beş ylllik verileri hasta bilgi kayıt sisteminden geriye dönük olarak incelendi. Tam kan test sonuçlarından nötrofil sayııı, lenfosit sayısı parametresine oranlanarak nötrofil lenfosit oranı ve trombosit lenfosit oran değerleri hesaplandt.

Bulgular Toplam 577 hasta enfeksiyona bağlı ateș grubu (EBAG) ve enfeksiyona bağh olmayan ateș grubu (EBOAG) olarak iki gruba ayrildi. Illk antibiyotik kullanım süreleri EBAG veEBOAG'da strastyla 4.54 \pm 3.08 (1-14) gün ve $5.35 \pm 3.8(1-21)$ gündü $(p=0.023)$. Nötrofil-lenfositorant (NLO) EBAG'da 8.00 (3.00-15.00)iken, EBOAG'da 5.00 (3.00-9.00)idi ( $p=0.001)$. Trombosit-lenfositorant (TLO) EBAG'da 21.00(9.00-41.00)iken, EBOAG'da 16.00 (7.25-27.75)idiveanlamldeğildi ( $p=0.165)$.

Sonuç Nötrofil lenfosit oranı rutin kan testlerinden bakılabilen ve pahalı bir yöntem olmaması nedeniyle, nedeni belirlenemeyen ateșli (NBA)hastalarda avantajl bir tanı metodu olarak kullanılabilir. 


\section{INTRODUCTION}

Fever of unknown origin (FUO) was initially described by Petersdorf and Beason as body temperature above 38.3 ${ }^{\circ} \mathrm{C}$. It is defined as fever that is not diagnosed despite on week of research on patients who had fever for at least three weeks and were eventually hospitalized. ${ }^{1}$ Although laboratory and diagnostic imaging tests contribute to advanced technology, challenges remain for FUO diagnosis and treatment. ${ }^{2}$ FUO consists of four general categories: infectious, neoplastic, non-infectious and others. ${ }^{3}$ In most previous studies, infections are indicated as the leading causes of FUO, in which abscess, endocarditis, tuberculosis and complicated urinary tract infections are the main ones. ${ }^{4}$ Adult-onset Still's disease (AOSD) and systemic lupus erythematosus are the most common reasons in young individuals of the Non-infectious inflammatory disease (NIID) group. Temporal arteritis and polymyalgia rheumatica are mostly defined in the elderly individuals of NIID group..$^{5}$

It is challenging to differentiate infectious fever from non-infectious on, which in turn makes it difficult to decide starting an antibiotic therapy in patients with non-infectious fever. In those cases, C-reactive protein (CRP) and procalcitonin(PCT) are important biomarkers to conclude whether an empirical antibiotic therapy should be initiated. ${ }^{6}$ Also, it has been suggested that the neutrophil: lymphocyte ratio (NLR) in peripheral blood is useful for distinguishing between types of infection and also useful for predicting the outcome of the infection. ${ }^{7}$

Proper empirical antibiotic treatment reduces mortality, along with the duration of intensive care unit and hospitalization. ${ }^{8}$ In some cases, antibiotic usage is not applicable. Unnecessary use of antibiotics should be avoided by considering appropriate antibiotic selection and antibiotic resistance on both patient and cost basis. Empirical antibiotic therapy should not be applied if the fever persists over a long time period. Antibiotic application might mask the disease, delay diagnosis and prevent appropriate treat- ment. One of the most common mistakes in antimicrobial usage is adding or changing antibiotics, although there is no clear evidence of an infectious disease., ${ }^{90}$

In this study, we aimed to investigate the distribution of antibiotic treatments applied to patients with FUO, who were admitted to our clinic due to fever and were hospitalized.

\section{MATERIAL and METHODS}

\section{Study site and study period}

This study was conducted between January 1, 2015 and January 1, 2020 at Sakarya Training and Research Hospital (SUTRH) Internal Medicine Clinic. SUTRH has total of 935 beds, in which 120 of them are in the intensive care unit (ICU). This study was performed in the internal medicine clinic of third step hospital, which has 36 beds. Patients who applied to the hospital with fever and received inpatient treatment at the internal medicine clinic were included in the study. Patients were evaluated in two groups as infection related fever group (IRFG) and non-infection related fever group (NIRFG), based on their fever etiologies.

\section{Infection Related Fever Group (IRFG)}

In this groups, the culture of patients, who applied to the clinic with fever, demonstrated reproduction, which is an indicative of an infectious disease.

\section{Non-Infection Related Fever Group (NIRFG)}

In this groups, the culture results of patients, who had fever and were followed up in the clinic turned out negative. Infections were excluded from the source of fever and this group is designated as non-infectious.

\section{Inclusion and exclusion criteria}

All patients being followed up at least one day at SUTRH Internal Medicine Clinic were included in the study. The study group consisted of patients who were admitted with fever. Patients who were followed up in the clinic for less 
than 1 day and whose medical records were missing were excluded from the study. Patients under 17 were not included from the study as well.

\section{Data collection}

The medical records of patients who were hospitalized at SUTRH Internal Medicine Clinic and admitted with fever were investigated retrospectively. The culture information of patients, antibiotics received, number of antibiotics administered, as well as initiation and duration of antibiotic usage were recorded on the patient registration form along with additional information regarding hospitalization.

Patient demographics, as well as PCT, CRP, erythrocytesedimentation rate (ESR), alanineaminotransferase (ALT), aspartate aminotransferase (AST), creatinine, thyroid stimulant hormone (TSH), lactatedehydrogenase (LDH), white blood cell (WBC), lymphocytes (Lym), neutrophil (Neu), mean platelet volume (MPV) and platelet levels were recorded.

\section{Laboratory parameters}

Blood samples were obtained in the morning, after eight hours of fasting during diagnosis and follow-up, and were sent to the laboratory immediately to be centrifuged at $2000 \mathrm{rpm}$ for 15 minutes. For biochemical parameters, the samples were placed into a dry tube and investigated using a Beckman Coulter AU680 ${ }^{\circledR}$ with Beckman Coulter kits. Blood was collected into an EDTA coated tube for hemogram examination using a WIC-LYSE for CELL DYN 3700 Kits on the Abbott Cell-Dyn $3700^{\circledR}$ Device.

ESR was performed using Rapida ESR $100^{\circledR}$ in capillary tubes. The CRP parameter was studied with SIEMENS BN II ${ }^{\oplus}$ with Cardio Phase CRP WN ${ }^{\oplus}$ kits. Blood samples for PCT were obtained from the tubes with decomposed serum. PCT was measured with a timely-mannered reinforced cryptate emission technology by measuring the signal sent by time lagged immunocomplex (BIOMERIEUX/ mini IDAS). TSH parameter was studied with Abbott Ar- chitect I $2000 \mathrm{SR}^{\circledast}$. The data was automatically uploaded to the hospital database system and screened consequently. MPV (N: 7.5- 11.5 femtoliter) values were recorded from the measured value in the hemogram.

\section{Statistical Analysis}

Data analysis was performed using IBM SPSS 21 (IBM Corp., Armonk, NY, USA ${ }^{\circledR} \mathrm{Z}$ ). All results are presented as frequencies, percentages, mean \pm S.D and median [IQR]. Chi-square test was used to compare categorical variables. Kolmogorov-Smirnov test was used to determine whether continuous data were normally distributed. All normally distributed data were analyzed using Student's t-test, while non-normally distributed data were analyzed using the Mann-Whitney $U$ test.The statistically significant two tailed p-value was considered as $<0.05$ unless otherwise noted.

\section{Ethics approval}

Ethics approval for this study was obtained from Sakarya University Faculty of Medicine Non-Interventional Ethics Committee (Number: 71522473 / 050.01.04/47).

\section{RESULTS}

Throughout the study period, 203 (36\%) of 577 patients, who were followed in the clinic for fever, were considered as IRFG and 374 (64\%) were NIRFG. In the IRFG, 133 $(65.5 \%)$ of patients were male, and the mean age was 66.42 \pm 16.58 years. Total of $206(55.1 \%)$ patients in the NIRFG were male, and the mean age was $65.41 \pm 18.03$ years. There was no significant difference between ages ( $p>0.05$ ). The length of hospitalization was similar in both groups, in which the average length of stay in NIRFG was $7.97 \pm$ 6.59 days and $8.85 \pm 7.6$ days in IRFG $(p=0.145$, Table 1$)$.

While the mean ESR in IRFG was found $71.47 \pm 34.28 \mathrm{~mm}$ / h; it was $62.68 \pm 39.29 \mathrm{~mm} / \mathrm{h}(\mathrm{N}:<50$ years; $<20 \mathrm{~mm} / \mathrm{h}$, $>50$ years; $<30 \mathrm{~mm} / \mathrm{h})$ in NIFRG $(\mathrm{p}=0.013)$. Mean CRP values were $141.82 \pm 107.19 \mathrm{mg} / \mathrm{L}$ and $97.49 \pm 88.77 \mathrm{mg} / \mathrm{L}$ $(\mathrm{N}:(\mathrm{N}: 0-5)$ in IRFG and NIFRG, respectively $(\mathrm{p}=0.001)$. 
Mean Alb levels were 2.91 \pm 0.60 in IRFG and NIFRG was $3.06 \pm 0.65 \mathrm{mg} / \mathrm{dL}(\mathrm{N}: 3,2-4,6) \mathrm{mg} / \mathrm{dL}$ in NIFRG $(\mathrm{p}=0,006)$. Median PCT in IRFG was $1.03(0.22-8.41) \mathrm{ng} / \mathrm{ml}$, whereas it was $0.36(0.09-1.11) \mathrm{ng} / \mathrm{ml}(\mathrm{N}:<0.5)$ in NIFRG. Median neutrophil-to-lymphocyte ratio (NLR) was 8.00 (3.0015.00) in the IRFG, whereas it was 5.00 (3.00-9) in the NIFRG $(\mathrm{p}=0.001)$. Median platelet-to-lymphocyte ratio (PLR) was 21.00 (9.00-41.00) in the IRFG, whereas it was $16.00(7.25-27.75)$ in the NIRFG and was not significant $(\mathrm{p}=0.001)$ (Table 2).

The distribution of hospitalization clinic was shown in table-1. The classification of diagnosis was extensively evaluated. Patients diagnosed with anemia and gastrointestinal bleeding were significantly higher in NIRFG $(\mathrm{p}<0.05)$. However, patients suffering from gastroenteritis, cellulitis, cholangitis, abscess, upper respiratory tract infection, sepsis, urinary tract infection, central venous catheter infection, diabetes mellitus and pneumonia were significantly higher in IRFG $(\mathrm{p}<0.05$, Table 1$)$.

Red blood distribution width, monocytes (\%), lymphocytes (\%), basophils (\%), albumin, iron, and folate levels significantly elevated in NIRFG compared to IRFG. Among laboratory parameters of IRFG, WBC, MCV, Hgb, neutrophil count, creatinine, CRP, PCT, and ESR levels were significantly higher than that of NIRFG. Other laboratory parameters were comparable in both groups (Table 2).

The time to initiate the first antibiotic was $2.12 \pm 1.98$ days in IRFG and $2.70 \pm 2.78$ days in NIRFG $(p=0.021)$. The duration of first antibiotic usage was $4.54 \pm 3.08$ and 5.35 \pm 3.8 days in IRFG and NIRFG, respectively, and there was a statistically significant difference between groups ( $\mathrm{p}=$ 0.023). Average number of antibiotics administered was $1.77 \pm 0.99$ in IRFG patients and $1.47 \pm 0.77$ in NIRFG patients, along with a significant difference between the groups $(\mathrm{p}=0.001)$ (Table 3$)$. The first empirical antibiotic was ceftriaxone, which was used by $82(40.1 \%)$ IRFG patients and $120(32.1 \%)$ NIRFG patients $(p=0.024)$. Secondly,moxifloxacin was administered to $36(17.7 \%)$ IRFG patients and $42(11.2 \%)$ NIRFG patients $(p=0.001)$. The final antibiotic was ampicillin- sulbactam and it was used by $17(8.4 \%)$ and 34 (9.1\%) patients od IRFG and NIRFG, respectively $(\mathrm{p}=0.155)$.

Table 1.Demographic data and diagnostic distribution of patients in non-infectious fever and infectious fever groups

\begin{tabular}{|l|c|c|c|}
\hline Features & $\begin{array}{c}\text { Non-infectious } \\
\text { Fever Group } \\
(\mathbf{n}: 374)\end{array}$ & $\begin{array}{c}\text { Infectious Fever } \\
\text { Group (n:203 }\end{array}$ & $\mathbf{P}$ \\
\hline Age & $65.41 \pm 18.03$ & $66.42 \pm 16.58$ & 0.509 \\
\hline Gender(male) & $206(55.1)$ & $133(65.5)$ & $\mathbf{0 . 0 1 5}$ \\
\hline Thyroid disease & $119(31.8)$ & $63(31.0)$ & 0.847 \\
\hline Gastroenteritis & 0 & $8(3.9)$ & $\mathbf{0 . 0 0 1}$ \\
\hline Cellulitis & 0 & $4(2.0)$ & $\mathbf{0 . 0 0 6}$ \\
\hline Cholangitis & 0 & $10(5.0)$ & $\mathbf{0 . 0 0 1}$ \\
\hline Abscess & 0 & $3(1.5)$ & $\mathbf{0 . 0 1 8}$ \\
\hline URTD & 0 & $6(3.0)$ & $\mathbf{0 . 0 0 1}$ \\
\hline Sepsis & $1(0.3)$ & $4(2.0)$ & $\mathbf{0 . 0 0 6}$ \\
\hline USI & $2(0.5)$ & $35(17.2)$ & $\mathbf{0 . 0 0 1}$ \\
\hline CRI & $128(34.2)$ & $9(4.4)$ & $\mathbf{0 . 0 0 1}$ \\
\hline DM & $71(19.0)$ & $16(7.9)$ & $\mathbf{0 . 0 0 1}$ \\
\hline Anemia & 0.009 \\
\hline Abbritions: & $0.3)$ & $\mathbf{0 . 0 0}$ & \\
\hline
\end{tabular}

Abbreviations: COPD; Chronic obstructive pulmonary disease, FMF;

Familial Mediterranean Fever, CCHF; Crimean-Congo hemorrhagic fever, ITP; Immune thrombocytopenic purpura, URTD; Upper respiratory tract diseases, USI; Urinary sytems infectious, IBD; Imphlamotory boweel disease, CRI; catheter-related infection, CVD; Cerebrovasular disease, DM; Diabetes Mellitus, CRF; Chronic renal failure, CHF; Congestive heart failure, GI: Gastrointestinal, HM; Hematologic malignancy, DCA; Diabetic ketoacidosis 
Table 2. Laboratory parameters of patients in non-infectious and infectious fever groups

\begin{tabular}{|c|c|c|c|}
\hline Parameters & $\begin{array}{l}\text { Non-infectious } \\
\text { Fever Group } \\
(\mathrm{n}: 374)\end{array}$ & $\begin{array}{l}\text { Infectious Fever } \\
\text { Group (n:203) }\end{array}$ & $\mathbf{P}$ \\
\hline $\begin{array}{l}\text { White blood cell } \\
\text { count, } 10^{3} / \mathrm{mm}^{3}\end{array}$ & $10.30 \pm 8.83$ & $12.30 \pm 10.20$ & 0.014 \\
\hline $\begin{array}{l}\text { Platelet count, } \\
10^{3} / \mathrm{mm}^{3}\end{array}$ & $232.26 \pm 123.96$ & $231.71 \pm 150.80$ & 0.963 \\
\hline $\begin{array}{l}\text { Neutrophil count, } \\
10^{3} / \mathrm{mm}^{3}\end{array}$ & $7.94 \pm 7.07$ & $9.65 \pm 6.40$ & 0.004 \\
\hline MCV & $85.37 \pm 13.74$ & $88.38 \pm 7.84$ & 0.004 \\
\hline $\begin{array}{l}\text { Lymphocyte count, } \\
10^{3} / \mathrm{mm}^{3}\end{array}$ & $1.58 \pm 3.04$ & $1.73 \pm 8.13$ & 0.743 \\
\hline Hemoglobin, g/dl & $9.63 \pm 2.66$ & $10.17 \pm 2.36$ & 0.017 \\
\hline Hematocrit, \% & $29.22 \pm 7.97$ & $30.48 \pm 7.40$ & 0.064 \\
\hline Albumin, gr/L & $3.06 \pm 0.65$ & $2.91 \pm 0.60$ & 0.006 \\
\hline ALT, IU/L & $19.00[11.00-39.00]$ & $16.50[10.00-38.00]$ & 0.195 \\
\hline AST, IU/L & $71.16 \pm 270.44$ & $54.13 \pm 113.7$ & 0.394 \\
\hline $\begin{array}{l}\text { C-reactive protein } \\
(\mathrm{CRP}), \mathrm{mg} / \mathrm{L}\end{array}$ & $97.49 \pm 88.77$ & $141.82 \pm 107.19$ & 0.001 \\
\hline $\begin{array}{l}\text { Sedimentation, } \\
\mathrm{mm} / \mathrm{h}\end{array}$ & $62.68 \pm 39.29$ & $71.47 \pm 34.28$ & 0.013 \\
\hline LDH, U/L & $460.80 \pm 876.02$ & $334.76 \pm 413.0$ & 0.094 \\
\hline $\begin{array}{l}\text { Procalcitonin, } \\
\mathrm{ng} / \mathrm{mL}\end{array}$ & $0.36[0.09-1.11]$ & $1.03[0.22-8.41]$ & 0.001 \\
\hline NLR & $5[3.00-9]$ & $8[3.00-15.00]$ & 0.001 \\
\hline PLR & $21.00(9.00-41.00)$ & $16.00(7.25-27.75)$ & 0.001 \\
\hline TSH & $0,93[0.45-1.69]$ & $0.77[0.35-1.48]$ & 0.139 \\
\hline
\end{tabular}

Abbreviations: MCV; Mean corpusculer volume, Alb; Albumine, ALT; Alanine aminotransferase, AST; aspartat aminotransferaz, CRP; C-reactive protein, LDH; Lactate dehydrogenase, ESR; Erythrocyte Sedimentation Rate, TSH; Thyroid-stimulating hormone, NLR; Neutrophil/Lymphocyte

\begin{tabular}{|c|c|c|c|}
\hline \multicolumn{4}{|c|}{$\begin{array}{l}\text { Table 3. Comparison of antibiotherapy in infectious and non-in- } \\
\text { fectious patients with fever }\end{array}$} \\
\hline Parameters & $\begin{array}{c}\text { Non-infectious } \\
\text { Fever Group } \\
(\mathbf{n}: 374)\end{array}$ & $\begin{array}{c}\text { Infectious } \\
\text { Fever Group } \\
(n: 203)\end{array}$ & $\mathbf{P}$ \\
\hline $\begin{array}{l}\text { First Antibiotic Start } \\
\text { Time (Day) }\end{array}$ & $2.70 \pm 2.78$ & $2.12 \pm 1.98$ & 0.021 \\
\hline $\begin{array}{l}\text { First Antibiotic Usage } \\
\text { Time (Day) }\end{array}$ & $5.35 \pm 3.8$ & $4.54 \pm 3.08$ & 0.023 \\
\hline Mean antibiotic count & $1.47 \pm 0.77$ & $1.77 \pm 0.99$ & 0.001 \\
\hline \multicolumn{4}{|c|}{ Frequently Used Antibiotics Respectively } \\
\hline Seftriakson & $120(\% 32.1)$ & $82(\% 40.1)$ & 0.024 \\
\hline Moksifloksasin & $42(\% 11.2)$ & $36(\% 17.7)$ & 0.001 \\
\hline Ampisilin/Sulbaktam & $34(\% 9.1)$ & $17(\% 8.4)$ & 0.155 \\
\hline $\begin{array}{l}\text { Piperasilin-Tazobak- } \\
\text { tam }\end{array}$ & $14(\% 3.7)$ & $9(\% 4.4)$ & 0.094 \\
\hline
\end{tabular}

\section{DISCUSSION}

In this study, it was observed that the time to start empirical antibiotics was delayed in NIRFG compared to IRFG. In addition, we observed that the number of antibiotics used in IRFG patients was significantly higher than that of NIRFG. The duration of empirical antibiotic usage was significantly longer in NIRFG with respect to IRFG. The reason behind his might be the fact that fever in NIFRG patients did not alleviate in spite of the antibiotics and the inflammatory markers did not improve. The most commonly used antibiotic was ceftriaxone since broad-spectrum antibiotics are prescribed with the approval of an infection disease specialist, and additionally third generation cephalosporins are widely preferred in prescriptions in accordance with legal regulations of our country. Quinolones were the second most commonly used antibiotics since they are accessible and their administration in oral form is relatively easy. Several studies have emphasized that shorter treatments ought to be applied considering the potential side effects, antibiotic resistant organisms, and increased costs. ${ }^{11-13}$

WBC is an indicator, which is actively used in fever identification. WBC levels elevate in IRFG, whereas they are low in NIRFG. CRP is another crucial indicator for the inflammatory response of the body. The proportion of patients with low hemoglobin and low serum albumin was higher in IRFG, while it was lower in NIRFG. In our study, we demonstrated that NIRFG patients represented significantly lower WBC, CRP, ESR, PCT, Hgb, MCV, neutrophil levels. This may be due to chronic anemia, which is a common consequence of hepcidin and cytokines such as TNF-alpha, IL1, IL6. ${ }^{14,15}$ Additionally, lower albumin levels in IRFG may occur due to the negative phase reactant in infectious diseases. ${ }^{16}$ Many randomized controlled trials have investigated the PCT levels to assist decisions regarding the administration of antibiotic therapy. ${ }^{17}$ In one study, PCT and CRP levels significantly increased in cancer patients with infection compared to those who didn't have infection and significantly elevated in all gastric can- 
cer groups with respect to the control group. CRP and PCT are two important markers for the diagnosis of infection in cancer patients. ${ }^{18}$ In another study, infected inactive SLE had a significantly higher CRP level than uninfected inactive SLE. ${ }^{19}$

In a study by Are Naess et al., it was shown that NLR was higher in patients hospitalized due to fever due to bacterial infection compared to those due to noninfectious causes. ${ }^{20}$ Similarly, in our study, NLR was found higher in IRFG, but lower in NIRFG. However, there was no significant difference in PLR. Pneumonia, catheter-related infection (CRI), Urinary system infections (USI), Upper respiratory tract diseases (URTD), abscess, cholangitis, cellulitis, gastroenteritis are commonly observed in IRFG since all of those diseases are infection related. It is common for diseases such as GI bleeding, anemia, diabetes, etc. to be significantly higher in the NIRFG. In community-acquired pneumonia, empirical antimicrobial therapy was applied to patients whose microbiological results have not yet been concluded. Guidelines suggest that empirical antibiotic treatment selection includes streptococci pneumonia and atypical pathogens. ${ }^{21,22}$ In several studies, no significant difference was observed between the use of macrolides, beta lactam antibiotics and fluoroquinolones in the antibiotic regimen in CAP patients. ${ }^{23}$ In our study, moxifloxacin antibiotics that belong to fluoroquinolone are detected to be widely used in pneumonia.

Our study has two important limiting factors, as the first being a retrospective study, and the second being a single-center study. Excluding other fever-related diseases might be another limitation of our study. However, our study makes significant contributions to the empirical antibiotic treatment of infection and non-infection related fever diseases.

Infections affect all organs and systems. People with diabetes often suffer from conditions including feet infections, malignant external otitis, rhinocerebral mucormycosis, and gangrenous cholecystitis. Infection process, in addition to increased morbidity, may be among the initial indicators of diabetes or may trigger factors for disease-specific complications such as diabetic ketoacidosis and hypoglycemia. ${ }^{24}$ Co-occurrence of fever and GI bleeding may suggest the presence of a concomitant infection disease.

As a result of this study, empirical antibiotic treatment management should be taken into consideration in comorbid diseases such as T2DM, thyroid diseases, chronic kidney disease (CKD), non-hematological malignancies(NHM), pneumonia, urinary tract infection (UTI) accompanied by fever. In patients with diabetes mellitus, fever is a common comorbidity factor in both infectious and non-infectious conditions. The most commonly observed comorbid infections are diabetes mellitus and CKD. Thus, additional consideration is required to control infection in those patients. The anamnesis of the patients should be taken carefully and the laboratory examinations should be evaluated clearly.

\section{CONCLUSION}

Clinicians are required to avoid using wide-spectrum antibiotic selection and exposing the patients to excessive antibiotics until the culture results are revealed. Some of the hemogram parameters such as NLR and PLR are easy, fast and inexpensive to use as a marker of patient outcome, can be useful in daily clinical practice and empirical antibiotic use in developing countries.

\section{Acknowledgments}

We would like to thank Sakarya Training and Research Hospital Internal Medicine Clinic for following the patients, the laboratory staff for performing the laboratory analysis, and the hospital doctors who allowed the patients to be scanned.

Ethics approval for this study was obtained from Sakarya University Faculty of Medicine Non-Interventional Ethics Committee (Number: 71522473 / 050.01.04/47). 
Sakarya Med J 2021;11(1):25-31

KARACAER et al., The Relationship Between Neutrophil-Lymphocyte Ratio

\section{References}

1. Petersdorf, R. G.,Beeson, P. B. Fever of unexplainedorigin: report on 100 cases. Medicine 1961;40, 1-30.

2. Vanderschueren S, Knockaert D, Adriaenssens T, Demey W, Durnez A, Blockmans D, et al. From prolonged febrile illness to fever of unknown origin: The challenge continues. Archives of Internal Medicine 2003;163:1033-1041.

3. Unger M, Karanikas G, Kerschbaumer A, Winkler S, Aletaha D. Fever of unknownorigin (FUO) revised. Wien KlinWochenschr 2016;128(21-22):796-801.

4. Steele GM, Franco-Paredes C, Chastain DB. Noninfectious causes of fever in adults. Nurse Practitioner 2018;43:38-44

5. Knockaert DC, Vanneste LJ, Bobbaers HJ. Fever of Unknown Origin in Elderly Patients. JAGS1993;41:1187-1192

6. Schuetz P, Albrich W, Mueller B. Procalcitonin for diagnosis of infection and guide to antibiotic decisions: past, present and future. BMC Med 2011;9:107.

7. Terradas R, Grau S, Blanch J, Riu, M., Saballs, P., Castells, X. et al.Eosinophilcountand neutrophil-lymphocyte count ratio as prognostic markers in patients with bacteremia: a retrospective cohort study. PLoSOne 2012;7(8):e42860.

8. Ferrer R, Martin-Loeches I, Phillips G, Osborn TM, Townsend S, Dellinger RP, et al. Empiric antibiotic treatment reduces mortality in severe sepsis and septic shock from the first hour: Results from a guideline-based performance improvement program. Critical Care Medicine 2014;42:1749-1755.

9. Davey P, Marwick CA, Scott CL, Charani E, McNeil K, Brown E, et al. Interventions to improve antibiotic prescribing practices for hospital inpatients. Cochrane Database Syst Rev 2017; 9:2(2):CD003543.

10. Bryan CS, Ahuja D. Fever of Unknown Origin: Is There a Role for Empiric Therapy? Infectious Disease Clinics of North America.Infect Dis Clin North Am 2007;21:1213-1220.

11. Katchman EA, Milo G, Paul M, Christiaens T, Baerheim A, Leibovici L, et al. Three-day vs longer duration of antibiotic treatment for cystitis in women: Systematic review and meta-analysis. American Journal of Medicine. Am J Med 2005;118:1196-1207.

12. Dunbar LM, Wunderink RG, Habib MP, Smith LG, Tennenberg AM, Khashab MM, et al. High-Dose, Short-Course Levofloxacin for Community-Acquired Pneumonia: A New Treatment Paradigm. Clin Infect Dis 2003;37:752-760.
13. Chastre J, Wolff M, Fagon JY, Chevret S, Thomas F, Wermert D, et al. Comparison of 8 vs 15 Days of Antibiotic Therapy for Ventilator-Associated Pneumonia in Adults: A Randomized Trial. JAMA 2003;290:2588-2598.

14. Madu AJ, Ughasoro MD. Anaemia of Chronic Disease: An In-Depth Review. Medical Principles and Practice. S. Karger AG 2017;26:1-9.

15. Weiss G. Iron metabolism in the anemia of chronic disease. Biochimica et Biophysica ActaGeneral Subjects. Elsevier 2009;1790: 682-693.

16. Mackowiak PA, Bartlett JG, Borden EC, Goldblum SE, Hasday JD, Munford RS, et al. Concepts of Fever: Recent Advances and Lingering Dogma. Clin InfectDis 1997;25:119-138.

17. Sager R, Kutz A, Mueller B, Schuetz P. Procalcitonin-guided diagnosis and antibiotic stewardship revisited. BMC Medicine. BioMed Central Ltd 2017;15:15

18. Ma, Y., Zhang, L., Rong, S., Qu, H., Zhang, Y., Chang, D. W., et al.Relationbetweengastriccancer and protein oxidation, DNA damage, and lipid peroxidation. OxidMed CellLongev (2013)2013.

19. Zhang CF, Xu R, Li MT, Zeng XF. A clinical analysis on fever of unknown origin in in-patients with systemic lupus erythematosus. Zhonghua Nei Ke Za Zhi 2017;56(4):295-297.

20. Naess A, Nilssen SS, Mo R, Eide GE, Sjursen H. Role of neutrophil to lymphocyte and monocyte to lymphocyte ratios in the diagnosis of bacterial infection in patients with fever. Infection 2017;45:299-307.

21. Mandell LA, Wunderink RG, Anzueto A, Bartlett JG, Campbell GD, Dean NC, et al. Infectious Diseases Society of America/American Thoracic Society Consensus Guidelines on the Management of Community-Acquired Pneumonia in Adults. Clin Infect Dis 2007;44:S2772

22. Lim, W. S., Baudouin, S. V., George, R. C., Hill, A. T., Jamieson, C., Le Jeune, I.,et al.PneumoniaGuidelines Committee of the BTS Standards of Care Committee. BTS guidelines for themanagement of communityacquiredpneumonia in adults 2009;64:3, iii1-iii55.

23. Çilli A, Sayiner A, Çelenk B, Şakar Coşkun A, Kilinç O, Hazar A., et al. Antibiotic treatment outcomes in community-acquired pneumonia. Turk J Med Sci 2018;48:730-736.

24. Alves C, Casqueiro J, Casqueiro J. Infections in patients with diabetes mellitus: A review of pathogenesis. Indian JEndocrinol Metab 2012;16:27. 